\title{
Commemorating the deadly other side of externalized borders through "migrant- martyrs", sacrifices and politizations of (irregular) migration on the international migrants' day in Mali
}

\author{
Almamy Sylla ${ }^{1}$ and Susanne U. Schultz ${ }^{2^{*}}$
}

\author{
*Correspondence: susanne.schultz@ \\ uni-bielefeld.de \\ ${ }^{2}$ Bielefeld Graduate School in \\ History and Sociology (BGHS), \\ Bielefeld University, \\ Universitätsstraße 25, 33615 \\ Bielefeld, Germany \\ Full list of author information is \\ available at the end of the article
}

\begin{abstract}
This article explores the different memorial strategies of the civil society associations and the public authorities in Mali through various practices and discourses of the International Migrant Day around the stinging reality of migrants' shipwrecks in the Mediterranean. Against the backdrop of the progressive externalization of European borders, the Libyan coast has become a hecatomb for young Malian migrant 'adventurers'. In 2015, around 360 young people from the region of Kayes, in the Southwest of Mali, lost their lives. Under the pressure of civil society associations, the government of Mali decreed days of National Mourning in memory of the shipwrecked. Simultaneously the transnational network Afrique-Europe-Interact in collaboration with representatives of the city of Kita, organized a politically ritualized ceremony to carry out sacrifices honoring the deaths. Based on an ethnography of this mourning ceremony, the article shows how civil society actors denounce the appropriation of the tragic events by a state that "expels" its citizens incapable to develop and the European Union that "kills" by externalizing borders. A short media analysis of the government's celebration serves as a contrast to the civil society engagement. Through these competing memorial strategies, the article presents the antagonistic but overlapping positionings between the public authorities with their northern partners condemning irregular migration, and the bereaved populations and the civil society considering migration as a normal strategy for a better life and cultural heritage. Our analysis reveals that the celebration of the International Migrants Day and the National Day of Mourning have led to the construction of alternative discourses on 'irregular' migration that call to account externalization and neoliberal policies and the risk-taking attitude of migrants in migratory tragedies embedded in very localized mourning practices.
\end{abstract}

Keywords: International migrant day, Commemoration, Shipwreck, Externalization, Mali, EU

\section{Introduction}

For more than two decades, the Mediterranean Sea has been one of the deadliest passages on the planet (see Albahari, 2015). The political crisis in North Africa and the

(c) The Author(s). 2020 Open Access This article is distributed under the terms of the Creative Commons Attribution 4.0 International License (http://creativecommons.org/licenses/by/4.0/), which permits unrestricted use, distribution, and reproduction in any medium, provided you give appropriate credit to the original author(s) and the source, provide a link to the Creative Commons license, and indicate if changes were made 
effects of the externalization policies of the European Union (EU) have made the crossing of the Mediterranean particularly deadly for undocumented sub-Saharan migrants. Since 2011 shipwrecks occur on an almost daily basis (Lemberg-Pedersen, 2017). SubSaharan migrants used the collapse of political regimes in North Africa as an opportunity to access Europe, particularly through Libya, which had been exercising rigorous control over the EU's maritime borders. The deaths of migrants have been recorded since 1993, with the loss of 34,500 lives up until 2017 (Dubuis, 2017). ${ }^{1}$ The postGaddafi period, however, was one of the deadliest with 13,545 alone lost at sea (see "Missing Migrants Project", n.d.). When on July 27, 2014, between 82 and 87 young Malians drowned off the coast of Tripoli, the presence of Malian migratory adventurers (see Bredeloup, 2008) on these dilapidated and overloaded boats (Alvarez, 2016) became a subject of public debate in the country (Coulibaly, 2014). The death of 800 people on April 19, 2015, including 184 Malians, eventually set off the 'refugee crisis' in Europe. These migratory tragedies resonated badly, and became the object of various appropriations, e.g. from the parents affected by the deaths of their children ${ }^{2}$ likewise the Malian public authorities and civil society organizations. The Malian government used the fatalities to denounce the dangers of 'irregular' ${ }^{3}$ migration, detentions, expulsions and repatriations of Malians, and to advocate for creating alternatives to youth emigration (Dao, 2015). This tragedy coincided with the adoption of the National Migration Policy (MMEIA, 2014). One of the major goals of this new policy was to secure and protect Malian migrants and to promote legal migration (see Koné, 2015). These tragedies grafted on to a global debate on the management of migrants and diasporic communities that for Mali was led by migrant associations denouncing the lack of protection of migrants by the State despite their contribution to the national economy. ${ }^{4}$ While the affected parents provided public testimonies on the valued economic roles of the shipwrecked on different occasions, state public discourses continued considering them as 'irregular' migrants. Effectively, the shipwrecks put the populations and public authorities to test giving place to various forms of taking charge of these shipwrecks, and eventually for antagonistic positions towards the management of 'irregular' migrations. These became particularly visible in celebrating the International Migrants Day ${ }^{5}$ in December 2015 in Kita and in Bamako. The latter built on a National Day of Mourning the Malian government had decreed in April, immediately following the massive shipwreck, prompted by harsh criticism by the civil society.

The argument of this article is that the celebration of the International Migrants Day and the National Mourning Day in the memory of the fatalities of the Mediterranean constitute arenas and a pretext for affirming the antagonistic, even if sometimes overlapping, positions of the different actors on migration management in Mali. The article

\footnotetext{
${ }^{1}$ The figures of shipwrecks in the Mediterranean are often vague, thus rather indicative for the actual number of fatalities. The blog "Fortress Europe" offers an unofficial estimate of the number of missing persons in the Mediterranean since 1988.

${ }^{2}$ Here it refers to those parents participating in the celebration of the International Migrant Day in Kita by providing testimonies on the migrants' roles for everyday life.

${ }^{3}$ We use the terms 'irregular', "illegal' or 'clandestine' migration as subject of a critical investigation, while the development and migrant associations in the region of Kayes prefer "forced emigration".

${ }^{4}$ The remittances of the Malian diaspora were estimated at one billion US dollars in 2017 (KNOMAD, 2018, p. 33).

${ }^{5}$ The International Migrants Day recalls the International Convention on the Protection of the Rights of All Migrant Workers and Members of Their Families of the United Nations (A/RES/55/93). Since 2003, in Mali, it serves for debates and festivities organized by the MMEIA and migrant associations.
} 
is set within the debate on the politization of the "backstage" of externalization reflecting "the current play and tragedy between borders and migrants" in the Mediterranean from "behind the scenes" (Gaibazzi, Bellagamba, \& Dünnwald, 2017, p. 4) by highlighting the actors, their discourses and actions from there. Focusing on the 'deadly other side' of externalized borders it is thus set within a debate on the practices of "governing migration through death" (Squire, 2016; see Albahari, 2015) which builds on Foucault's work on "biopolitics", what Mbembe calls "necropolitics" (Mbembe \& Meintjes, 2003) and Agamben's concept of "bare life" (Agamben, 1998). Such is encountered, as the article shows, by mobilization of the different actors, not least through a "politics of mourning" (Alonso \& Nienass, 2016; Rygiel, 2016; von Bieberstein \& Evren, 2016). Methodologically, the article thus takes the perspective of an ethnography of mourning (Klass, 2006; Rosaldo, 1988) of the migrant fatalities, that is to say a 'commemoration in the absence of bodies' (see Bolt, 2018). This is contrasted with a short media and interview analysis of the government's ceremony to adequately grasp the antagonisms of the different actors on the ways to approach and to deal with irregular migrants. Through this twofold approach, the article sheds light on very specific, yet barely known elements of the concrete and contextualized effects and reactions to externalization and the politics of mourning, in particular, involving a variety of actors and their different positionings.

The data presented derives from our doctoral research on involuntary return migration in Mali. Within this context we participated in and observed the commemoration of the shipwrecked migrants in Kita in December 2015. Further, we followed the parallel and previous (media) debate and events in Bamako related to the deaths and the discursive constructions against irregular migrations and spoke to some of the actors (e.g. civil society, activists, parents of shipwrecked, former deportees, government and local authorities). Kita was chosen as a research site as it had received a significant number of expelled migrants from Mauritania, Morocco, Spain, and since 2002, repatriates from Côte d'Ivoire, likewise from Libya, particularly around 2011. In 2015 it continued to be a place of high-frequency migration and consequently considerable numbers of shipwrecked. Over the course of 2015, 360 of a total of 372 shipwrecked estimated the same year, originated from the region of Kayes, where Kita is located. The article, first, shows the course of the Migrant Day 2015 and the interventions of the various actors, initiated by the Malian section of Afrique-Europe-Interact (AEI) ${ }^{6}$ and the Malian Association of Deportees (AME) in Kita, further the government's activities in Bamako dealing with alternative ways to keep young people in place. Secondly, it contextualizes the effects of and reactions to externalizing migration policies against the background of self-evident "cultures of migration" (Hahn \& Klute, 2007) and 'migratory cultural heritage'. Finally, the article analyses the different commemoration strategies along their political, symbolic, and economic meanings in form of a sacrifice for the shipwrecked, the dead migrants' 'martyrization' and the particular role of 'irregular' migration herein. Externalization thus creates a frame and pretext for action, while generating deeply localized dimensions of contestation and ritualization simultaneously.

${ }^{6} \mathrm{AEI}$ is a transnational network of activists, deportees and migrants from Mali, Togo, Germany, Austria, the Netherlands, created in 2010. It aims at denouncing EU migration policy, and drawing attention to the structural causes of migration while demanding a just and self-determined development. 


\section{In the field: faces of "solidarity"}

On December 18, 2015, we left with the AEI delegation from Bamako to Kita. The following day was planned as a day of reflection and commemoration of the missing migrants in the Mediterranean. This commemoration took place as part of the celebration of the International Migrants Day. Simultaneously, in the capital Bamako, Aminata Dramane Traoré, a renowned Malian intellectual, activist and former politician, organized a forum to which she invited the Malian government, the IOM, a representative of the United Nations and the International Bank of Mali. This forum aimed to examine the negative social impacts of irregular migration and to ignite the possibilities of retaining young people to stay (Daou, 2015). On the other hand, the activists' departure from Bamako for the ceremony in Kita was set by the organizers on Friday afternoon, 1 day before the event. Being closely related to some of the activists and not least for methodological precautions, we, the two authors, travelled in the same bus also accompanied by other travelers. The lull in the car of Mandé-Trans, one of the main companies operating between Kita and Bamako after the shutdown of the Trans-rail passenger train, was constantly disturbed by the slogan "solidarity" and heated discussions between activists:

First activist: Solidarity! Solidarity! Second activist: You do not see that you are disturbing others; we are not the only ones in the bus. First activist: No, no! We fight for all Malians, who are worthy of this name. In my understanding, there is not a single family in Mali, not affected in one way or another by shipwrecks in the Mediterranean (Dialogue between activists, fieldnotes, 18.12.2015).

Although there was a diverse audience in the bus, the two associate spokespersons meant to mark their presence by resorting to the rhetoric of "solidarity" in the name of all Malian shipwrecks and their affected families. They seemingly had found a new slogan to legitimize, even nationalize their fight for a "just and borderless world", using the disturbing context of the shipwrecks, which was charged with emotions. In Kita, the proposal to commune with the bereaved families through such an event was received very favorably. Not in the least because this initiative was accompanied by an attempt at making Europe and the Malian State responsible for the tragedies. The use of the rhetoric of "solidarity" was supposed to share with the mourning families the sorrow over the missing migrants as economic pillars and supporters of their families. Moreover, the ceremony provided a space for the people in Kita to exchange experiences and emotions of the fundamental ruptures caused by the deaths of community and family members, but also of the almost everyday and still shameful deportations and expulsions. Eventually, this reflected on the effects of restrictive migratory policies in a locality of 'limited' economic resources. While an involuntary return implies at least the chance for some kind of continuation, the wreck of a young breadwinner can mean the loss of social status for an entire family and the impossibility of achieving the economic goals expected from the migratory project (see Bredeloup, 2017; Koenig, 2005).

For the commemoration, parents of the shipwrecked assembled with a large number of repatriates and deportees; further deputies of the administrative authorities in Kita and transnational activists. This created "a new community" (Stierl, 
2016) in grief and honoring the dead (Rygiel, 2016, p. 557). The local AEI representatives had mobilized widely over the previous weeks. Several local radio spots broadcasted the event. The celebration started early in the morning with the sacrifice of an ox for the deaths through the city's principal imam. Some founding families of Kita and a local representative of AEI were allowed to participate in the ceremony. Even if it was invisible for most participants, this ritual element of sacrifice was of central symbolic significance for commemorating the dead bodies, which were absent. The sacrifice of an ox sets the dead into the 'normal' order a of a funeral practice to symbolically 'allow their rest and salvation'. In the absence of wrecked migrant bodies, the codified religious service helps parents to feel connected to the deceased (Klass, 2006), eventually mourn in a dignifying and relieving way (cf. Bolt, 2018; Squire, 2016). This enables symbolically recovering some of the great loss caused by the politically externalized borders. The idea of the sacrifice had popped up several weeks before, when the Malian section of AEI had been organizing the event. Their Kita counterparts had even travelled to Bamako for the meetings. This meant a four to five hour drive over a paved, but bumpy, road, to share high emotions and heated discussions. This pro-activist attitude could relate to an urgency to partake and gain something, widespread among the oftenprecarious civil society organizations in Mali. Furthermore, as the activists in the bus exclaimed, it was a "fight for all Malians" which made everybody affected by the migrants' deaths and obliged to commemorate.

The introductory speeches of the local authorities during the main commemoration in Kita harshly denunciated the attitude of the Malian government regarding the treatments of Malians abroad. Here, the diverging opposition rather blended from the local to the national level instead of from official authorities to civil society. It underlines a connectedness of the local actors, including authorities, in being affected by the migrants' fatalities, thus collectively calling authorities at the national level to more responsiveness. In addition, the declaration of the Malian section of AEI set the EU in the center of responsibility in denouncing the political, economic inequalities of restrictive border protection policies, and their corollaries, the extinction of many migrants' lives (Afrique-europe-interact, 2015). Several of the parents burst out in tears when offered to share their testimonies describing the difficulties they faced. It seemed an appropriate space of expression on the population's exceptional and daily worries, deeply engrained through migratory practices and their current effects.

Beyond the sacrifice, the religious services and the call for resistance and "solidarity", the civil society appealed to the State for more support of peanut cultivation. The Head of the principals of the different districts in Kita, a dignified and honorable person, put it as follows,

Before, we only knew emigration to Libya. Without emigration, however, the world will not be better. We congratulate those who had the idea to organize this ceremony. We need to start enhancing the culture of certain crops so that our children can stay here. I ask the State to revitalize the peanut cultivation. If development projects support the financing of maize and peanut crops, our children will not migrate. They will be busy in doing something. (fieldnotes, 19.12.2015, Kita) 
Young people are seen as 'forced' to leave. A valorization of the agriculture through the government, however, would guarantee to retain "the valid arms on the spot" (fieldnotes, 19.12.2015). This discourse resembles the one of the government and the forum organized by Aminata Dramane Traoré. Otherwise, this seems to paradoxically 'devalue' the role of migrations through staying by promoting to abandon established migratory practices. Beyond the social importance of peanut processing in Kita, the demand of local actors for more public efforts could be part of a resource capture strategy benefiting the development of migrants' communities of origin. Since a reorientation in the EU's cooperation with Mali within the Global Approach to Migration and Mobility (GAMM) in 2005 and the recent implementation of the Valetta Process, the development of migrants' "home" territories through "the return to the land" (Gary-Tounkara, 2008) has become a new economic opening for these actors, above all the diaspora. Apart from this global framework that links migration with development and empowers local actors in their community development, the argument raised does not completely stand up to a critical analysis of the economic situation. Kita, unlike most districts in the Kayes region, still benefits from relatively favorable climatic and soil conditions for the diversification of crops. Nevertheless, the cultivation of cotton introduced by the Malian State in compensation for destructing the groundnut sector is denounced by the civil society. The speakers do not put this relatively bright agricultural situation in Kita in perspective. It is possible that these appeals to the State are rather symbolic and nostalgic acts on the pretext of the Migrants Day, like trying to explain the 'irregular' migration of young people and their deadly consequences.

Contrariwise, the International Migrants Day celebrated in Bamako under the leadership of Aminata Dramane Traoré, with close involvement of the Ministry of Malians Abroad, stood in continuation of the National Mourning Day as decreed by the government for 30 April 2015. This day had already served to denounce 'irregular' migration. Over the course of a 3 days celebration of the Migrants Day in Bamako, former and potential migrants, artists and intellectuals, and mothers having lost their children, could share their experiences and work on solutions (Programme "Migrances 2015", 2015; interview with diaspora representative, 18.01.2016). The Ministry representative advertised to fight 'irregular' migration, but also to provide "an employment policy to retain the young candidates from emigrating" and "to valorize the emigrants already abroad and their economic contributions" (Dembélé, 2016). The main slogan circulated was "Never again! That's enough irregular immigration! Mali is our El Dorado" ("Célébration de la Journée internationale des Migrants," 2015). Even if the two parallel celebrations of the International Migrant Day in Bamako, as a continuation of the National Mourning Day in April, and the commemoration in Kita included partially similar actors and seemingly overlapping rhetoric, the event in Kita created a distinct opposition to the State, harshly accusing it as responsible for the shipwrecks together with the EU. While both events address alternative ways to the deaths through migration, the calling to accounts differ. At the very center stands a diverging view of and approach to 'irregular' migration as to be demonstrated in the following. The stances on the roles of migrants and their counter-effects build on a broad debate on migration management in Mali. Firstly, we will provide the relevant context of migration and politics in Mali. 


\section{Politics of (irregular) migration in Mali between management, contestation and protection}

Mali is considered a country providing 'irregular' migrants and a transit country for sub-Saharans to the North. It is said to be the critical place for the development of historical and contemporary migratory circuits linking the two banks of the Sahara (Bredeloup \& Pliez, 2005), thus displaying of a true cultural heritage of migration. ${ }^{7}$

It was in 1996 that former migrants expelled from different European and African countries formed the AME to support other deported and to denounce the "inhumane" migration policies from the Global North and South. Since then, the involvement of migrant associations and other civil society actors around the migration issue have become of paramount importance in the Malian public debate, influencing the formation of political institutions (Siméant, 2014). The funds and public attention raised parallel to the progressive externalization of EU borders facilitated this process. With the shooting of migrants in Ceuta and Melilla in 2005, and unprecedented media coverage (see Stock, Üstübici, \& Schultz, 2019 and Tyszler, 2019 in this issue), a new type of response to the EU had been emerging at the level of migrant-sending countries through the activism of migrant associations supported by European civil society groups (Dünnwald, 2017). This political and institutional setting in Mali also favored the formulation of alternative discourses on the migration management. Under the pressure of migrant associations, the Malian government is said to have twice refused signing readmission agreements with France in 2009 (Soukouna, 2012) and with the EU in 2016/17 (Traoré, 2016).

Mali is at the forefront of the externalization policies of the EU (Dünnwald, 2017, p. 89). Unlike Morocco or Libya (under Gaddafi) with genuine technologies for border management and the control of migrants (Coutin, 2014), Mali applies a policy of "double interest" and "double discourse" (Dünnwald, 2017, p. 96), resulting in a rather ambivalent approach to managing 'irregular' migration. In 2008, the EU established the Center for Information and Migration Management (CIGEM) with an overall objective to support the development and implementation of a Malian migration policy with particular emphasis on "migration and development" (European Commission, 2011). At the end of the CIGEM project, in February 2015, the impression of AME representatives and EU officials in Bamako was that the center had "flopped" in achieving its objectives (field interviews, Bamako, 22 and 24.10.2014). The basic criticism was that it served for receiving deportees instead of creating jobs and promoting legal migration as previously announced (Feldman, 2012). Following the virtual failure of a pioneering experience in managing migration in sub-Saharan Africa, the EU decided to remove migration as an area of intervention in the document of its strategic agenda 2014-2020 for Mali (European Commission, 2015). However, with the 'refugee crisis' of 2015, the EU has given a new impetus to its political orientation on migration in the region. This followed the establishment of the PONAM; in its primary form one of the concrete outcomes of CIGEM, the directives of the Valetta summit and the EU focus "to readmit deportees and contain (potential) migrants" toward the North (Korvensyrjä, 2017, p. 193). This renewed EU interest in migration inaugurated an ever more intense phase of externalizing its borders in response to the established migration governance in Mali. It

\footnotetext{
${ }^{7}$ "This builds on "cultures of migration" as "....complexes of cultural representations" (Hahn \& Klute, 2007, p.11), the related lifestyle and historical background legitimating migration.
} 
consisted of the collaboration among international actors (i.e. the French Office of Immigration and Integration, Technical Co-development Unit, the Spanish, Italian, Swiss, German representations, the IOM, other United Nations entities) and Malian state actors, including the Ministry of Malians Abroad and African Integration (MMEIA, 2014), and the Agency for the Promotion of Youth Employment (fieldnotes, 2017). For two decades, such attempts of externalization have been theorized as "policing at a distance" (Bigo \& Guild, 2005) or "borderscapes" (Lemberg-Pedersen, 2017).

In this second wave of externalization, Mali was chosen as "priority country" together with Niger, Nigeria, Senegal and Ethiopia to establish Migration Partnerships with the EU (European Commission, 2016). The new European Agenda on Migration is accompanied by an Emergency Trust Fund of 3.39 billion Euro, of which 80 million Euro are specifically assigned to migration management in Mali. ${ }^{8}$

Civil society organizations did not stay behind in this new progression of European borders on the African continent. Simultaneously, the multiplicity of actors and interweaving issues has created new challenges around the Trust Fund. It can legitimize 'their presence'. A similar notion applies to the State. Beyond that, it visualizes the institutionalization of European aid to the civil society through a real flexible externalization of development support.

The district of Kita is considered as a region of international emigration par excellence (Konaté \& Gonin, 2016, p. 25). Mostly inhabited by Malinke, Kakolo and Fulani, there are municipalities where emigrants have developed models of public, political, and economic investments and connectivity through constructing schools, health centers and roads (Galatowitsch, 2009; Lima, 2005), and thus positioning themselves as true agents of development. This builds on the (historically) grown cultures of circular migration, nomadism and ritual journeys (Hahn \& Klute, 2007), which are characterized though "migratory adventures"' (Bredeloup, 2008) and dynamic transnational spaces today (Manchuelle, 1997). However, the post-colonial international emigration was spurred by the "rail crisis' and the closure of the state-owned oil mills between 1986 and 1995 because of a more pro-active liberal economic state policy (Lachenmann, 1986). Kita's economy was based on the high production and processing of peanuts and the commercial transactions along the railway. Export revenues of groundnuts fell in Mali, Senegal and Gambia by 50 to 80\% from 1960 to 1980 (Badiane \& Kinteh, 1994, p. 6). The transfer to Mali's Cotton Mill incited a new pioneering migration front towards Senegal and Côte d'Ivoire. ${ }^{9}$ Due to increased possibilities of mobility through processes of globalization and the political unrest in the 1990s in Côte d'Ivoire, many of Kita's emigrants moved further North (Mauritania, Morocco, Spain and Italy). Between 2004 and 2008, however, Libya outplayed other migratory destinations among Kita's young migrants (Konaté \& Gonin, 2016, pp. 117-119). This coincided with the EU experimenting one of the most rigorous border management policies in Libya, including massive deportations. Not only the migratory restrictions and difficult conditions during emigration did not allow a dignified and successful stay. The previous

\footnotetext{
${ }^{8}$ The fund allocated to Mali aims to help immigrants to stay; to compel the State to regulate the migrant flow and welcome 'undesirable' citizens from Europe; establish deterrence measures for potential emigration candidates (European Commission, 2018).

${ }^{9}$ Colonization caused the first displacements of population, while the great droughts $(1972-74,1984,2002)$ fostered the idea in Kita to increase agricultural incomes by migrating in the sub-region and to Europe (Konaté \& Gonin, 2016, pp. 104-5).
} 
circularity of migration was forcefully interrupted. Large numbers of Malians and other sub-Saharans, including the people in Kita, were forced to return in an undignified way, to take dangerous routes to (re-)migrate or to remain involuntarily immobile (e.g. Jónsson, 2007). As a response to this new phenomenon of massive involuntary returns, an effect of the progressive externalization of EU borders, and in particular the Libyan crisis 2011, short-lived return assistance programs were tested in some villages of Kita by the IOM and the Kita branch of the Association of Repatriates of Mali between 2006 and 2010 (Field Investigations, November 2017). In some villages, a large proportion of repatriated and deported remained there after their migratory failure, engaging in agricultural activities or in petty trade. In other villages most of the young repatriated and deported are planning to re-emigrate or exercise a form of circular migration between their villages and informal gold mining sites in Mali and the sub-region (Hilson \& Garforth, 2012).

While migration in Mali, and particularly in Kita, has become a strategic resource and way for seeking a better life, it has also become subject to an unprecedented politization, in particular since the massive returns as described. All this creates a space of contestation, which is subject to various appropriations of migration policies. The celebrations of the International Migrants Day were set in this political, social and cultural context.

They can thus be understood as the willingness of civil society organizations and the State to participate in the debate on the effects of EU outsourcing policies and to propose endogenous alternatives to 'irregular' migration. We will further flesh out the course of politization to developing localized mourning strategies in the following.

\section{From the politization of migrant shipwrecks in the Mediterranean to "migrant-martyrs"}

Deportations and repatriations of Malians had long been dominating the public debate. Since 2014, migrants' shipwrecks in the Mediterranean have been a main focus, more recently accompanied by the deaths in the Sahara desert, which increasingly reach the public conscience (Samake, 2017; Stierl, 2016). Most recently, a civil societal Alarmphone for the Sahara has been set up, among others with the help of the AEI. Further, migrant shipwrecks have become an object of the production of memorial strategies by public authorities, civil society actors and local communities in Mali.

It started with the event of 87 Malians missing in the Mediterranean in July 2014, of which 69 came from the region of Kayes (EMDK, October 2014, unpublished Mission Report). On that occasion, the Minister of Malians Abroad organized a press conference to inform the public about the risks of 'irregular' migration and to support legal migration through the CIGEM, which in that moment was already almost out of function. As first of its kind, he announced an official delegation to offer condolences to shipwrecked' parents (Coulibaly, 2014). The reaction of civil society actors followed promptly. A press conference of the AME and the EMDK assailed:

The poor governance and repeated multi-faceted crises are stifling development programs and restraining the initiatives, particularly at the base of the social sectors [...]. In a word: well-being. To find answers to these causes, candidates undertake migratory projects at the risk of their lives along roads that have become increasingly deadly 
since the creation of Frontex [...] and the signing of agreements between the EU [...]. Mali has not escaped this rule (Association Malienne des Expulses, 2014).

During the civil society conference, relatives of the dead provided testimonies. All their positions aimed at deconstructing the hegemonic position of the State fighting 'irregular' migration. In addition to this dissident political agenda, an open letter from the Coordination of Associations of Nationals of the Kayes Region (CADERKA) to the President of the Malian Republic explicitly stated the government's responsibility for the risky migrations and for the first time called on declaring a day of national mourning:

CADERKA is irritated that our Government has shown no sign of national mourning. [...] The candidates for adventure will prefer to face all the risks of forced emigration (instead of clandestine, illegal or irregular emigration...). They are forced to leave against the uncertainty of their self-realization in the country and the indifference of our governments with the common denominator of poor governance (CADERKA, Unpublished Open Letter, August 08, 2014).

One year later, when 360 migrants from Kayes region died in the Mediterranean, the EMDK $^{10}$ tone became more drastic: "the region of Kayes is mourning!" (EMDK, April 28, 2015, Unpublished Manifesto). It became a broad alliance of human rights and migrant associations, politicians and the media demanding from the government a dignified day of mourning for the deaths. Facing a persistent civil society pressure, the government declared April 30th as "National Day of Mourning for the victims of shipwrecks in the Mediterranean and on the Niger River in Tienfala" ("Mali: Communique du Conseil des Ministres," 2015). It invited people to organize community prayers for the repose of the souls of the shipwrecked all over the national territory. Some associations felt, however, that this National Day and the collective prayers were not a sufficiently symbolic commitment. In this vein, the ritualized sacrifices in Kita tried to correct these shortcomings. The AEI representatives in Kita, Bamako, and from Germany, and the local AME representation, consequently thought to organize the International Migrants Day not as a festivity, but as a day of mourning and commemoration.

The different celebrations of the State vis-à-vis the civil society and bereaved communities resulted from two ways of appropriating the International Migrants Day on 18 December 2015 based on diverging discourses on (irregular) migration. First, in continuation of the National Mourning Day on April 30, the Malian authorities tried to strengthen the campaign against 'irregular' migration by indexing it together with the trafficking of migrants as the main causes of shipwrecks at Aminata Dramane Traorés event organized for the Migrants Day. Secondly, the perspective of migrant associations, supported by parents and representatives of Kita's founding families, blamed the shipwrecks on the neoliberal orientation of the State and its destructing the environment of candidates for 'irregular' migration. In this vein, the youth is "forced" to emigrate due to privatization and the collapse of state-owned companies.

\footnotetext{
${ }^{10}$ These estimates are just the tip of the iceberg, considering that shipwrecks without testimonies have been more important. In addition, the fatalities' count was based on telephone calls with migrants' families, EMDK missions, the AME, MMEIA and statistics from the district Prefectures (fieldnotes, December 2015).
} 
While the perspective on the neoliberal economy is certainly key for understanding contemporary migratory movements in Mali, it does not suffice as analytical framework. Beyond the economic dimension, said "cultures of migration" and the migratory cultural heritage are necessary analytical tools to understand the inclination to become "kamikaze migrants" (Hernández-Carretero \& Carling, 2012) among the youth in Kita and for creating its corollary, the deadly side of externalized borders. It is collective prayers and sacrifices to the dead, which should eventually build an appropriate cultural heritage: while the memorial strategy of the government was to declare a Day of National Mourning and to organize community prayers for the souls of the shipwrecked, the commemoration in Kita was committed to the symbolism of funerals. Both constituted strategies to build cultural heritage (upon migratory tragedies) understood as a "process by which a supposedly 'traditional' social or cultural fact sees its practice voluntarily 're-launched"' (Charles-Dominique, 2013, p. 75). In the eyes of the representatives in Kita, the State's mourning, was not appropriate, however, as it was detached from a social practice that 'must' include a ritual sacrifice of funerals and mourning. In contrast, the commemoration in Kita included this central element ${ }^{11}$. Eventually this was to correct a character of abnormality conferred by the absence of bodies caused by the shipwrecks (see Bolt, 2018).

In the collective conscience, the funerary rites allow the deceased to be integrated into the pantheon of the dead (Holas, 1956, p.14). These local practices are embellished by a malékite ${ }^{12}$ Muslim tradition. In that sense, the descendants or the parents of the deceased perpetuate the funeral rite according to a very definite period as regards commemorative prayers (Ziyara). The idea behind this ritual is that the religious services allow the rest of the soul of the deceased person. These popular and rather customary sacrifices eventually acquired a symbolic power in the Malian Muslim world. Lacking the central element of the sacrifice, the official appropriation of migrants' shipwrecks through the government's declaration of a National Mourning Day cannot correspond to the local practices of mourning at the level of the communities of origin of the fatalities, as it built on collective prayers only. In Kita, these communities and a transnational network succeeded in responding to the abnormality created by the EU's externalized borders in adapting the local ritual practice through a well-organized event. This creates a sacrifice of particular character. Usually, the appropriate procedure for a burial is to wait until twenty-four hours after the death. In the case of death at sea or high costs of repatriation of the body, the burial time limit of twenty-four hours is rarely respected (Baron, 2015; Heller \& Pécoud, 2018; Schmoll, Thiollet, \& Wihtol de Wenden, 2015). Thousands of anonymous deaths have not received a proper Muslim funerary rite. From this point of view, the ceremonies in Mali were done to correct the exceeding burial period though collective prayers, on the one hand, and a collective sacrifice, on the other hand, for the repose of the soul of the deceased. They contribute to building cultural heritage processes in the sense of Charles-Dominique (2013) as they allow the deceased to leave anonymity and to be valued by the State and the communities of origin in a more dignified and humane way; eventually to letting them go.

\footnotetext{
${ }^{11}$ The sacrifices to the dead, though of paramount importance, are considered by Muslim reformist tendencies as blameful innovations- bid'a- (Holder \& Olivier, 2014, p. 263).

${ }^{12}$ Malikism, founded by Mālik ibn Anas (711-795, "Medina), a theologian and legislator, is one of the four classical schools of Sunni Muslim law, in majority followed in North and West Africa.
} 


\section{Martyrization of migrants on the spot}

The decisive move in Kita is further to elevate the missing persons to the status of "martyrs" due to their roles as economic agents and "local constructors" (Soukouna, 2016). Herein the memorial becomes an object of cultural heritage, which embodies the spirit of the dead. A speaker on the day praised the migrants' value for their communities:

If the children go on migration, leaving their father and their mother, it's because there is no well-being in the village. When leaving, they are aware of two things: either they will die before getting what they went out for; or they will have the chance to realize their dreams. The first thing you have in front of your eyes is death; and yet they leave to help their old mothers, fathers and their brothers (K.M., Kita, fieldnotes, 19.12.2015).

From the perspective of this collective imaginary, and beyond any idea of publicity or associative appropriation, the day of commemoration in Kita can gain its full meaning. The symbolic elevation of the dead to martyrs in addition to the sacrifice enables transgressing the required time, absolving the abnormal character of the commemoration, and moreover, the migrants' death.

Just as little as, the politization of the shipwrecks of the Mediterranean through the State's Day of Mourning matches the popular idea of collective sacrifices (in the sense of a cultural heritage), ${ }^{13}$ the international and national discourse about 'irregular' migrants meet the expectations of the communities of origin of shipwrecked. In fact, these communities make a change of perspective. In addition to the established cultures of migration as a cultural heritage itself, many young people appreciate and accept risk taking readily because of the migrants' social investments. There are barely alternative discourses that would discourage the perilous adventures. Contrariwise, a collective imaginary exists in these communities stigmatizing the immobility of young people by considering it as a breakdown in the adolescent life cycle (Gonin \& Kotlok, 2012), especially for a man. In other words, risk taking is an attribute of masculinity. The migratory adventure is considered "the first individual or collective experience of a man" (Dougnon, 2012, p. 154). Nevertheless, with the effects of the externalized EU borders on deportee numbers and migrants' deaths in recent years, there are more young people and their parents who declare they will stay and engage on the spot. Only by deciphering these local conceptions of (irregular) migration, the symbolic significance of the commemorative day in Kita can be measured. Beyond the local appropriation of shipwrecks through the collective sacrifice, there is an attempt to martyrize the migrants wrecked through the figure of the migrant "kamikaze" (Hernández-Carretero \& Carling, 2012). From this point of view, the "procedure of installation", as an adapted "re-launch" of the "traditional" practice (Charles-Dominique, 2013, p. 73-75) of the shipwrecked migrants and their 'martyrization' is very interesting in the construction of an alternative discourse on 'irregular' migration. Especially as the merits of the new migration policy in Mali are simultaneously praised by state-run media on that day. These

13“'Cultural heritage [...] also includes traditions [...] such as [...] social practices, rituals and festive events [...] concerning nature and the universe or the knowledge and skills necessary for traditional craftsmanship" (UNESCO, 2003). 
"installation procedures" and 'martyrization' as part of the celebration in Kita thus become competing strategies to the National Mourning Day. They restore a positive picture of 'irregular' migration in the local context in opposition to the official narrative of fighting this form of migration, even if in the end to also avoid the risky migratory adventures and migrants' death.

The arguments raised on the courage and bravery of the migrants who "must be praised", not only value and legitimize 'irregular' migration, but likewise legitimize the organizations managing and dealing with it, be it through justifying or fighting it. Denouncing the public policies with regard to the creation of wealth and jobs, and making the EU responsible for the dehumanizing management of the resulting migrations, is thus a virtual campaign against the neoliberal State and public policies.

The effects of the EU externalization policies herein provide a platform and simultaneously theme for its contestation on this day. By bringing externalization in line with the effects of neoliberal policies fostered by the State, which actually "force" migration and its actors' deaths as depicted, the protest can be seen as claiming externalization as part of the neoliberal world order. Beyond this politization and activism, the sacrifice and martyrization can only symbolically and literally adapt to what appears as an abnormality in the ritual procedure. As an answer to the deadly reverse of externalized borders, they constitute local responses in building cultural heritage on the role of (irregular) migration and its actors.

\section{Conclusion}

Based on our findings, the article has demonstrated that the communities at origin of the deceased and civil society have alternative readings of the border externalization policies, making the EU and the neoliberal Malian state responsible of migration tragedies in the Mediterranean. To this end, they develop deeply localized practices of a "politics of mourning" against it. The commemorative celebrations during the International Migrants Day and the National Day of Mourning serve as pretext for affirming the antagonistic and also overlapping positions of the actors marginalized by EU externalization and the migration management in Mali. All the initiatives presented here, of the civil society and public authorities, contribute to an attempt of building a cultural heritage on the phenomenon of migration. In the region of Kayes this relates to cultures of migration which have become even more important because of the "little state engagement in the cultivation of peanuts" and the effects of neoliberal and democratic policies. For these reasons, awareness-raising campaigns by public authorities and international organizations have little impact on the communities of 'irregular' migrants, who reject the term itself, arguing that it is defined by those who consider subSaharan migration as a problem. Such structuring of the debate gives evidence that the different actors have been deploying each their own strategies according to a political, associative, activist, developmentalist or a humanist agenda.

We have contextualized our findings in view of this significance and sensitivity of the migration issue in Mali. Migration has become a phenomenon of fetish, like "a god-thing" (Bazin, 2008); due to the importance of the income generated, the migrants' role and the political construction that accompanies it (Lima, 2005; Quiminal, 2002). Thus, wanting to denounce the counter-effects of this (migratory) culture, fortified by the European border externalization, is hard to be accepted, even if these are deadly in their contemporary form. In this sense, the commemoration day in Kita, beyond the mourning and publicity, 
is an opportunity to celebrate migrants as "martyrs" for their importance for the community development. Even if the State's discourse on the occasion of its Migrant Day celebration is to fight "irregular' migration, it is promoting a "double discourse" of valorizing migrants and promoting legal migratory ways, also in collaboration with the civil society. The Malian state and civil society actors utilize or avoid utilizing the notion of 'irregular' migrant according to the actions they develop and the audiences they target. Eventually, it is about discussing the role of (irregular) migration in society. Not least this provides legitimacy to the existence of the State in relation to international donors and for the civil society to form a transnational counter power.

Since the commemoration day organized by the AEI in Kita in 2015, expulsions and shipwrecks of young Malians have continued. The number of associations of repatriates and former deportees steadily increases. Some of them are supported by the AME and AEI. This dynamic associative movement connects to the social riots of the suppressed workers of the oil mills and Malian railway. The connections between these various forms of political activism make Kita and Bamako outposts of contesting and affirming the EU externalization regime.

Our article contributes to the debate on a "politics of mourning" in the face of externalization of borders to Sub-Saharan Africa. It particularly highlights the role of social practices and the development of counter-discourses in mourning in the absence of corpses. The ethnographical perspective allows capturing grounded strategies and positionings of the diverse actors in the arena of (irregular) migration management in light of the deadly consequences of the EU's externalized borders, importantly in the communities of origin. Centrally it could envisage the symbolism of the ritualized sacrifice as one key to correspond to prescribed funeral practices, bring back the dead souls, and not least relieve the mourning community. More ethnographic research is needed on migrants' deaths mourning and its politizations to capture such local effects and responses to border externalization, and eventually to link it to a broader debate on the 'biopolitics' of irregular migration.

\begin{abstract}
Abbreviations
AEl: Afrique-Europe-Interact; AME: Association Malienne des Expulsés [Engl.: Malian Association for Deportees]; CADERKA: Coordination des Associations des Ressortissants de la Région de Kayes [Engl. Coordination of National Associations of Kayes Region]; CIGEM: Centre pour I'Information et Gestion des Migrations [Engl.: Center for Information and Migration Management]; EMDK: Espace Migrations et Développement de la région de Kayes [Engl.: Migration and Development Area of the Kayes Region]; EU: European Union; GAMM: Global Approach to Migration and Mobility; IOM: International Organisation for Migration; MMEIA: Ministère des Maliens de l'Extérieur et l'Intégration Africaine [Engl.: Ministry of Malians Abroad and African Integration]; PONAM: Politique Nationale de Migration [Engl.: National Migration Policy]; UNESCO: United Nations Educational, Scientific and Cultural Organization
\end{abstract}

Authors' contributions

Both authors read and approved the final manuscript.

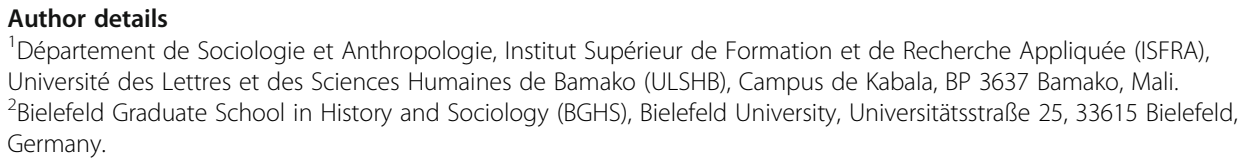


Albahari, M. (2015). Crimes of peace. Mediterranean migrations at the World's deadliest border. Philadelphia: University of Pennsylvania Press.

Alonso, A.-D., \& Nienass, B. (2016). Deaths, visibility, and responsibility: The politics of mourning at the US-Mexico border. Social Research, 83(2), 421-451 URL: https://muse.jhu.edu/article/631168/pdf.

Alvarez, D. (2016). Unstable vessels small boats as emblems of deaths foretold and as harbingers of better futures in figurations of irregular migration across the strait of Gibraltar. In L. Mannik (Ed.), Migration by boat. Discourses of trauma, exclusion, and survival, (pp. 116-136). New York: Berghan Books.

Association Malienne des Expulses (2014). Naufrage du 28 juillet sur les côtes libyennes [July 28, sinking on the Libyan coast]. Retrieved from http://www.expulsesmaliens.info/Naufrage-du-28-juillet-sur-les.html.

Badiane, O., \& Kinteh, S. (1994). Trade pessimism and regionalism in African countries: The case of groundnut exporters (IFPRI, Research Report no. 97). International Food Policy Research Institute, Washington.

Baron, L. (2015, April 24). Migrants: des morts sans sépulture? [Migrants: dead without burial?].TV5-Monde, April 24, 2015. https://information.tv5monde.com/info/migrants-des-morts-sans-sepulture-30135. Accessed 10 Apr 2018.

Bazin, J. (2008). Retour aux choses-dieux [Back to god-things]. In A. Bensa, \& V. Descombes (Eds.), Des clous dans la Joconde [Nails in the Mona Lisa]. L'anthropologie autrement, (pp. 493-520). Toulouse: Editions Anarchardis.

Bigo, D., \& Guild, E. (2005). Policing at a distance: Schengen visa policies. In D. Bigo, \& E. Guild (Eds.), Controlling Frontiers. Free movement into and within Europe, (pp. 233-263). Hants and Burlington: Ashgate.

Bolt, S. (2018). 'In the absence of a corpse: Rituals for body donors in the Netherlands. In A. C. G. Robben (Ed.), A companion to the anthropology of death, (pp. 371-381). Hoboken: Wiley Blackwell.

Bredeloup, S. (2008). L'Aventurier, une figure de la migration africaine [The Adventurer, a figure of African migration]. Cahiers Internationales de Sociologie, 125(2), 281-306. https://doi.org/10.3917/cis.125.0281.

Bredeloup, S. (2017). The migratory adventure as a moral experience. In N. Kleist, \& D. Thorsen (Eds.), Hope and uncertainty in contemporary African migration, (pp. 134-153). New York: Routledge.

Bredeloup, S., \& Pliez, O. (2005). Migrations entre les deux rives du Sahara [Migrations between the two shores of the Sahara]. Autrepart, (36), 3-20. Retrieved from http://www.documentation.ird.fr/hor/fdi:010035952.

Célébration de la Journée Internationale des Migrants [Celebration of International Migrants Day] (2015, December 21). [video file]. Retrieved from http://news.abamako.com/v/48180.html.

Charles-Dominique, L. (2013). La patrimonialisation des formes musicales et artistiques: Anthropologie d'une notion problématique [The patrimonialization of musical and artistic forms: Anthropology of a problematic notion]. Ethnologies, 35(1), 75-101. https://doi.org/10.7202/1026452ar.

Coordination des Associations de Développement des Cercles de la Région de Kayes à Bamako [CADERKA] (2014, August 08). Unpublished Open Letter. In A. Koné, Mort de plus de 200 émigrés maliens par noyage: La CADERKA s'étonne que notre Gouvernement n'ait manifesté aucun signe de deuil national [Death of more than 200 Malian emigrants by drowning: CADERKA is surprised that our Government has shown no sign of national mourning]. August 18, 2014. https:// notrenation.com/Mort-de-plus-de-200-emigres. Accessed July 15, 2018.

Coulibaly, F. (2014, August 6). [Le ministre des Maliens de l'extérieur, Abdrahamane Sylla à propos du récent naufrage en Libye d'une embarcation clandestine] [Minister of Foreign Malians Abdrahamane Sylla on the recent sinking of an illegal boat in Libya]. Retrieved from http://news.abamako.com/h/50930.html.

Coutin, S. B. (2014). Deportation Studies: Origins, Themes and Directions. Journal of Ethnic and Migration Studies. https://doi. org/10.1080/1369183X.2014.957175.

Dao, B. (2015, May 6). Contre la migration irrégulière: Croisade annoncée contre les passeurs [Against irregular migration: Crusade announced against smugglers]. L'Indicateur du Renouveau. Retrieved from http://malijet.com/la_societe_ malienne_aujourdhui/128864-contre-la-migration-irreguliere-croisade-annoncee-contre-les-pas.html.

Daou, O. (2015, December). Journée internationale des migrants: Plus de 4 millions de Maliens vivent à l'étranger [International Migrants Day: More than 4 million Malians live abroad]. L'Indicateur du Renouveau. Retrieved from http:// www.malinet.net/alerte/journee-internationale-des-migrants-plus-de-4-millionsde-maliens-vivent-a-letranger/.

Dembélé, D. M. (2016, January 6). Célébration de la Journée internationale des migrants: Il faut une politique d'emploi de rétention des jeunes candidats à l'émigration [Celebrating International Migrants Day: Retention employment policy for young emigration candidates]. L'Informateur. Retrieved from http://malijet.com/a_la_une_du_mali/143434-c\%C3\%A9|\% C3\%A9bration-de-la-journ\%C3\%A9e-internationale-des-migrants-il-faut-un.html.

Dougnon, I. (2012). Migration of children and youth in Mali: Global versus local discourses. In G. Spittler, \& M. Bourdillon (Eds.), African children at work. Working and learning and growing up for life, (pp. 143-167). LIT Verlag: Münster.

Dubuis, É. (2017, December 13). Le cimetière marin. 15000 hommes, femmes et enfants sont morts en Méditerranée depuis 2014. Le Temps. Retrieved from https://www.letemps.ch/grand-format/cimetiere-marin-mediterranee.

Dünnwald, S. (2017). Bamako, outpost of the European border regime? In P. Gaibazzi, S. Dünnwald, \& A. Bellagamba (Eds.), EurAfrican Borders and Migration Management Political Cultures, Contested Spaces, and Ordinary Lives, (pp. 83-107). New York: Palgrave Macmillan.

Espace Migrations et Développement de la région de Kayes [EMDK] (2014, October). EMDK Mission Report in the Bafoulabe District for the implementation of advocacy and humanitarian Actions following the shipwreck of candidates for Migration (Nationals of the Bafoulabé district), Unpublished report. GRDR/Assemblée régionale de Kayes.

Espace Migrations et Développement de la région de Kayes [EMDK] (2015, April 28). Naufrages en Méditerranée, la Région de Kayes en deuil! [Shipwrecks in the Mediterranean, the Kayes Region in mourning!] Unpublished Manifesto. Le Conseil Régional de Kayes.

European Commission (2011). Communication de la commission au parlement européen, au conseil, au comité économique et social européen et au comité des régions. Approche globale de la question des migrations et de la mobilité [Communication from the Commission to the European Parliament, the Council, the European Economic and Social Committee and the Committee of the Regions. Global approach to the issue of migration and mobility]. Retrieved from https://eur-lex.europa. eu/legal-content/FR/TXT/PDF/?uri=CELEX:52011DC0743\&from=EN.

European Commission (2015). Union Européene - Mali. Programme Indicatif National 2014-2020 [European Union - Mali. National Indicative Program 2014-2020]. Retrieved from https://ec.europa.eu/europeaid/sites/devco/files/pin-mali-fed11-2 014_fr.pdf. 
European Commission (2016, June 7). Commission announces New Migration Partnership Framework: reinforced cooperation with third countries to better manage migration [Press release]. Retrieved from http://europa.eu/rapid/press-release_IP-16-2 072_en.htm.

European Commission (2018). The EU Emergency Trust Fund for Africa. Retrieved from https://ec.europa.eu/europeaid/regions/ africa/eu-emergency-trust-fundafrica_en.

Feldman, G. (2012). The migration apparatus: Security, labor, and policymaking in the European Union. Stanford: Stanford University Press.

Gaibazzi, P., Bellagamba, A., \& S. Dünnwald (2017). Introduction: An Afro-Europeanist perspective on EurAfrican borders. In P. Gaibazzi, A. Bellagamba, \& S. Dünnwald (Eds.), EurAfrican Borders and Migration Management Political Cultures, Contested Spaces, and Ordinary Lives, (3-28). New York: Palgrave Macmillan.

Galatowitsch, D. (2009). Co-development in Mali: A Case Study of a Development Phenomenon Exploited by Immigration Policy (ISP Collection. Paper 737). Retrieved from https://afrique-europe-interact.net/files/co-development_in_mali_a_case_ study_of_a_development_phenomenon.pdf.

Gary-Tounkara, D. (2008). Migrants soudanais/maliens et conscience ivoirienne. Les étrangers en Côte d'lvoire [Sudanese / Malian migrants and Ivorian conscience. Foreigners in Ivory Coast (1903-1980). Paris: Collection Études africaines.

Gonin, P., \& Kotlok, N. (2012). Migrations et pauvreté: essai sur la situation malienne [Migration and poverty: an essay on the Malian situation]. CERISCOPE Pauvreté. Retrieved from http://ceriscope.sciences-po.fr/pauvrete/content/part2/migrationset-pauvrete-essai-sur-la-situation-malienne.

Hahn, H.-P., \& Klute, G. (2007). Cultures of migration. African perspectives. Berlin: LIT Verlag.

Heller, C., \& Pécoud, A. (2018). Counting migrants' deaths at the border: From civil society counter-statistics to (inter)governmental recuperation (IMI Working Papers series, p. 143).

Hernández-Carretero, M., \& Carling, J. (2012). Beyond "Kamikaze Migrants": Risk Taking in West African Boat Migration to Europe. Human Organization, 71(4), 407-416 https://doi.org/10.17730/humo.71.4.n52709742v2637t1.

Hilson, G., \& Garforth, C. (2012). 'Agricultural poverty' and the expansion of artisanal Mining in sub-Saharan Africa: Experiences from Southwest Mali and Southeast Ghana. Population Research and Policy Review, 31(3), 435-464. https://doi.org/10. 1007/s11113-012-9229-6.

Holas, B. (1956). Fondements spirituels de la vie sociale sénoufo [Spiritual Foundations of Senufo Social Life]. Journal des Africanistes, 26, 9-31. https://doi.org/10.3406/jafr.1956.1940.

Holder, G., \& Olivier, E. (2014). Le Maouloud de Djenné: stratégies patrimoniales de l'islam, mémoire urbaine et identité nationale [The Maouloud of Djenné: heritage strategies of Islam, urban memory and national identity]. In J. Brunet-Jailly, J. Charmes, \& D. Konaté (Eds.), Le Mali contemporain, (pp. 263-294). Bamako: Editions Tombouctou et IRD.

Jónsson, G. (2007). The mirage of migration. Migration aspirations and immobility in a Malian Soninke village (Unpublished master's thesis). University of Copenhagen.

Klass, D. (2006). Continuing conversation about continuing bonds. Death Studies, 30(9), 843-858. https://doi.org/10.1080/ 07481180600886959.

Koenig, D. (2005). Multilocality and social stratification in Kita, Mali. In L. Trager (Ed.), Migration and economy. Global and local dynamics, (pp. 77-102). Oxford: Alta Mira Press.

Konaté, F.-O., \& Gonin, P. (2016). Le rôle des migrations au Mali. Cercles de Kita, Banamba et district de Bamako [The role of migration in Mali. Circles of Kita, Banamba and district of Bamako]. Paris: L'Harmattan.

Koné, M. T. (2015, May 25). Mali: Politique nationale de migration: 120 milliards de FCFA pour faire de la migration un facteur de développement [Mali: National migration policy: CFAF 120 billion to make migration a factor of development]. L'Indépendant. Retrieved from http://maliactu.net/mali-politiquenationale-de-migration-120-milliards-de-fcfa-pour-faire-dela-migration-un-facteur-de-developpement/. Accessed 4 July 2018.

KNOMAD (2018, April). Migration and remittances. Recent Developments and Outlook. Special topic: Transit migration (Migration and Development Brief 29). Retrieved from http://www.knomad.org/sites/default/files/2018-04/Migration\%20and\%2 ODevelopment\%20Brief\%2029.pdf.

Korvensyrjä, A. (2017). The Valletta process and the Westphalian imaginary of migration research. Movements, 3(1), $192-204$. Retrieved from http://movements-journal.org/issues/04.bewegungen/14.korvensyrjae-valletta-process-westphalianimaginary-migration-research.html.

Lachenmann, G. (1986). Rural development in Mali - Destabilisation and social organisation. Quarterly Journal of International Agriculture, 25(3), 217-233.

Lemberg-Pedersen, M. (2017). Effective protection or effective combat? EU border control and North Africa. In P. Gaibazzi, S. Dünnwald, \& A. Bellagamba (Eds.), EurAfrican borders and migration management. Political cultures, contested spaces, and ordinary lives, (pp. 29-60). New York: Palgrave Macmillan.

Lima, S. (2005). La frontière "impossible"? Espace mobile, frontière et territoire. Le cas de la région de Kayes (Mali) [The "Impossible" Boundary? Mobile Space, Boundary and Territory. The Case of Kayes Area (Mali)]. Espace populations sociétés, 2, 277-291. https://doi.org/10.4000/eps.3103

Mali: Communiqué du Conseil des Ministres (2015, April 29). Retrieved from http://maliactu.net/mali-communique-du-conseildes-ministres-du-mercredi-29-avril-2015/.

Manchuelle, F. (1997). Willing migrants. Soninke labor diasporas, 1848-1960. Athens: Ohio University Press.

Mbembe, J.-A., \& Meintjes, L. (2003). Necropolitics. Public Culture, 15(1), 11-40 URL: https://muse.jhu.edu/article/39984.

Missing Migrants Project, Missing migrants. Traficking deaths along migratory routes. https://missingmigrants.iom.int/region/ mediterranean. Accessed 4 July 2018.

MMEIA (2014). Document de la Politique National de Migration pour le Mali [Document of the National Migration Policy for Mali] (PONAM). Bamako. Retrieved from http://maliens-exterieur.gouv.ml/.

Programme "Migrances 2015"(2015, 16-19 December). "Migrances 2015": Climat, migrations et sécurité humaine. Les intellectuels et les artistes s'engagent aussi. Les mères sociales aussi. [Climate, migrations and human security. Intellectuals and artists also get involved. Social mothers too.] Unpublished document.

Quiminal, C. (2002). Retours contraints, retours construits des émigrés maliens [Forced returns, returns made by Malian emigrants]. Hommes et Migrations, 1236, 35-43. Retrieved from http://www.revuesplurielles.org/_uploads/ pdf/8_1236_6.pdf. 
Rosaldo, R. (1988). Death in the ethnographic present. Poetics Today, 9(2), 425-434. https://doi.org/10.2307/1772697.

Rygiel, K. (2016). Dying to live: Migrant deaths and citizenship politics along European borders: Transgressions, disruptions, and mobilizations. Citizenship Studies, 20(5), 545-560. https://doi.org/10.1080/13621025.2016.1182682.

Samake, N. (2017, October 27). Calvaire des migrants Maliens dans le Sahara: Les Maliens rapatriés d'Algérie racontent l'enfer vécu [Calvary Malian migrants in the Sahara: Malians repatriated from Algeria tell the hell lived]. Le Républicain. Retrieved from https://www.info-mali.com/calvaire-des-migrants-maliens-dans-le-sahara-les-maliens-rapatries-dalgerie-racontentlenfer-vecu/.

Schmoll, C., Thiollet, H., \& Wihtol de Wenden, C. (2015). Migrations en Méditerranée. Paris: CNRS-Editions.

Siméant, J. (2014). Contester au Mali: Formes de la mobilisation et de la critique à Bamako [Contest in Mali: Forms of mobilization and criticism in Bamako]. Paris: Karthala.

Soukouna, S. (2012). L'Échec d'une coopération franco malienne sur les migrations: les logiques du refus malien de signer [The Failure of Franco-Malian cooperation on migration: the logic of the Malian refusal to sign] (Unpublished Master's thesis). Recueil Alexandries. Collections Masters. Retrieved from http://www.reseau-terra.eu/article1238.html.

Soukouna, S. (2016). Les bâtisseurs locaux du lien entre migration et développement : la coopération décentralisée d'ille-de-France au prisme des alliances stratégiques entre migrants maliens et pouvoirs locaux dans la région de Kayes au Mali [Local builders of the link between migration and development: the decentralized cooperation of lle-de-France in the prism of strategic alliances between Malian migrants and local authorities in the region of Kayes in Mali] (Unpublished Doctoral thesis). Ecole doctorale en sciences politiques. Paris: Paris 1.

Squire, V. (2016). Governing migration through death in Europe and the US: Identification, burial and the crisis of modern humanism. European Journal of International Relations, 1-20. https://doi.org/10.1177/135406611666866.

Stierl, M. (2016). A sea of struggle - Activist border interventions in the Mediterranean Sea. Citizenship Studies, 20(5), 561-578. https://doi.org/10.1080/13621025.2016.1182683.

Stock, l., Üstübici, A. \& Schultz, S.U. (2019). Externalization at work: responses to migration policies from the Global South. Comparative Migration Studies, 7. https://doi.org/10.1186/s40878-019-0157-z.

Traoré, K. (2016, December 19). Le Mali dément catégoriquement tout accord de réadmission avec I'UE [Mali categorically denies any readmission agreement with the EU]. Voa Afrique. Retrieved from https://www.voaafrique.com/a/le-malidement-categoriquement-tout-accord-de-readmission-avec-ue/3642156.htm.

Tyszler, E. (2019). From controlling mobilities to control over women's bodies: gendered effects of EU border externalization in Morocco. Comparative Migration Studies, 7. 10.1186/s40878-019-0128-4.

UNESCO (2003). Convention pour la sauvegarde du patrimoine culturel, immatériel, adoptée par la Conférence générale de I'UNESCO le 17 octobre 2003 [Convention for the safeguarding of the cultural heritage. intangible, adopted by the General Conference of UNESCO on 17 October 2003]. Retrieved from https://ich.unesco.org/doc/src/01852-FR.pdf.

von Bieberstein, A., \& Evren, E. (2016). From aggressive humanism to improper mourning: Burying the victims of Europe's border regime in Berlin. Social Research, 83(2), 453-479 URL: https://muse.jhu.edu/article/631169/pdf.

\section{Publisher's Note}

Springer Nature remains neutral with regard to jurisdictional claims in published maps and institutional affiliations.

\section{Submit your manuscript to a SpringerOpen ${ }^{\circ}$ journal and benefit from:}

- Convenient online submission

- Rigorous peer review

- Open access: articles freely available online

- High visibility within the field

- Retaining the copyright to your article

Submit your next manuscript at $\mathbf{s p r i n g e r o p e n . c o m ~}$ 